\title{
Characterization and Evaluation of Ceramic Properties with Spherical and Prismatic Samples of Clay Used in Red Ceramics
}

\author{
Alessandra Savazzini-Reis ${ }^{*}$, Viviana Possamai Della Sagrillo ${ }^{a}$,Jailson do Nascimento de Oliveira ${ }^{a}$, \\ Petterson Gonçalves Teixeira ${ }^{a}$, Francisco Rolando Valenzuela-Diaz ${ }^{b}$ \\ ${ }^{a}$ Instituto Federal de Educação, Ciência e Tecnologia do Espírito Santo - IFES, Espírito Santo, ES, Brazil \\ ${ }^{b}$ Escola Politécnica, Universidade de São Paulo - USP, São Paulo, SP, Brazil
}

Received: December 04, 2016; Revised: August 16, 2017; Accepted: October 05, 2017

\begin{abstract}
The Brazilian red ceramic industry monthly consumes about 10.3 million tons of clay, its main raw material. In most potteries, characterization of the clay is made empirically, which can result in roof tiles and blocks not according to standards. In this sense, this paper aims to characterize clays used in the manufacturing of red ceramic products in a factory located in Colatina-ES, which appears as a ceramic pole with about twenty small and midsize industries. The clays were characterized by: X-ray fluorescence, X-ray diffraction, thermal analysis (DSC/TG), granulometry, Atterberg limits and content of organic matter. Specimens of clay and mixture containing four clays were shaped. Specimens were shaped, dried at $110^{\circ} \mathrm{C}$, and burned at $850^{\circ} \mathrm{C}$ in an industrial furnace-type tunnel for 24 hours. The ceramics and mechanical properties evaluated were: mechanic strength, water absorption, apparent porosity, apparent specific mass and shrinkage by drying and firing. The characterization showed that kaolinitic clay presents high plasticity, but high porosity. The mixture formed by the four clays does not meet the requirements of the Brazilian standard clays for red ceramic. It is possible to confirm the use of the methodology of the spheres in potteries for analysis of ceramics raw materials.
\end{abstract}

Keywords: clays characterization, red ceramics, ceramic properties, spheres and prismatic samples

\section{Introduction}

The clayey raw material is natural, earthy, fine-grained, and susceptible to the modeling on the basis of the plastic consistency that it acquires in the presence of a certain amount of water ${ }^{1,2}$. The clays may present chemical and mineralogical compositions, different color and plasticity depending on the formation and change factors during their consolidation ${ }^{3}$. These chemical and mineralogical characteristics, in addition to the physical and microstructural, interrelate and influence the ceramic properties of roof tiles and blocks, the final products of the red ceramic industry.

Through ceramic tests in clayey specimens it is possible to classify and compare it with the established limits for ceramic properties of the Brazilian standard clays stipulated by Souza Santos $(1975)^{2}$, and to verify if the clay or clayey mixture is really suitable or not for that purpose. From the characterization of the clay can be proposed changes in the production process to suit and improve the characteristics that are desired from the final products.

However, the clayey raw material used in the Brazilian factories, in most cases, is chosen empirically, without characterization tests and classification of use. This fact makes standardization difficult and influences the quality of the final product ${ }^{4,5}$ generating nonconformity with the standards.

*e-mail: alessandrar@ifes.edu.br
The Brazilian red ceramics industry consumes about 10.3 million tons of clay per month, its main raw material, to produce roof tiles and blocks that are used in the construction industry ${ }^{6}$.

Considering the importance of the characterization of clays in use in industrial processes, also emphasized by Morais and Sposto $^{7}$ and Macedo et al. ${ }^{8}$, this paper aims to characterize four clays used in the manufacture of red ceramics products in the ceramic industry located in Colatina-ES-BR, which has a ceramic pole with about twenty small and mediumsized companies supplying the region and neighboring cities.

\section{Materials and Methods}

Samples of clays were collected in the raw material storage piles of the red ceramic industry located in the State of Espírito Santo-BR. After that, the four clays were broken with the aid of a pounder, homogenized and quartered.

Part of the material was used for characterization tests and part for making prismatic pressed specimens (bars) and samples shaped manually (spheres) to verify ceramic properties of the clays following the recommendation of Souza Santos $(1975)^{2}$ regarding the type of conformation of clayey samples.

For the manufacture of the bars, the clays were sieved in \# 80 sieve $(0.18 \mathrm{~mm}$ opening mesh) of ABNT (Brazilian 
Association of Technical Standards), according to the methodology proposed in Souza Santos ${ }^{2}$. For manufacture of the spheres, the clays were sieved in \# 40 sieve $(0.42 \mathrm{~mm}$ opening mesh) of ABNT, according to the methodology proposed by Laboratory of Non-Metallic Materials Persio de Souza Santos (LPSS) of PMT-EPUSP-SP-BR by researcher Francisco Rolando Valenzuela Diaz.

The clays were characterized by X-ray fluorescence (XRF) in Philips PW2400 spectrometer; X-ray diffraction (XRD) with copper source ( $\mathrm{K} \alpha$ radiation) in Philips $\mathrm{X}$ Pert MPD equipment; thermal analysis using differential scanning calorimetry (DSC), thermogravimetric (TG) with a heating rate of $10^{\circ} \mathrm{C} / \mathrm{min}$ in air atmosphere at Shimadzu DTA-50; particle size analysis by laser diffraction in Malvern Mastersizer 2000 equipment; Atterberg limits according to the procedure specified in ABNT (Brazilian Association of Technical Standards $)^{9,10}$ and analysis of organic matter by loss of mass by ignition ${ }^{11}$.

The identification of the samples in the DRX was done by comparison with files of the standard Crystallographic Open Database - $\mathrm{COD}^{12}$.

The bars were produced with a dry mass of $10 \mathrm{~g}$ and a moisture content of $10 \%$, measuring $20 \mathrm{~mm}$ x $60 \mathrm{~mm} \times 5$ $\mathrm{mm}$ by axial pressing at $250 \mathrm{Kgfcm}^{-2}$ in Marcon press with a capacity of $15 \mathrm{t}$. The spheres were manually molded with dry mass of $10 \mathrm{~g}$ and diameter of $20 \mathrm{~mm}$ with a moisture content enough for manual molding. Test specimens were produced for each clay and for the mixture containing the four clays in the industrial dosage.

The specimens (Fig. 1a) were oven dried for 24 hours at $110^{\circ} \mathrm{C}$, after that, drying shrinkage was measured. Then, the specimens were burned (Fig.1b) in an industrial furnace-type tunnel (Fig.1c) for 24 hours at a maximum temperature of $850^{\circ} \mathrm{C}$ in a structural ceramic industry in ES.

The four clays were called in the search as A, B, C and D. The clay content in the industrial dosage (in mass) used in the red ceramic industry is: clay A $(24.0 \%)$, clay B $(24.0 \%)$, clay $\mathrm{C}(12.5 \%)$ and clay $\mathrm{D}(39.5 \%)$. The industrial dosage was called "4clay".

Spheres and bars were produced with the four clays and with industrial dosage (4clay). For each clay and industrial dosage were shaped 6 spheres and 12 bars.

The loss on ignition, water absorption, apparent porosity, apparent specific mass, linear, linear shrinkage of burning on the burned specimens and shrinkage of drying on the dried specimens were analyzed. The compressive strength was measured in the spheres, and the flexural strength was measured in the bars. The values obtained were calculated by the arithmetic average considering the standard deviation.

\section{Results and Discussion}

From the results of the chemical analysis (Table 1) it can be verified that the four clays consist essentially of silica and

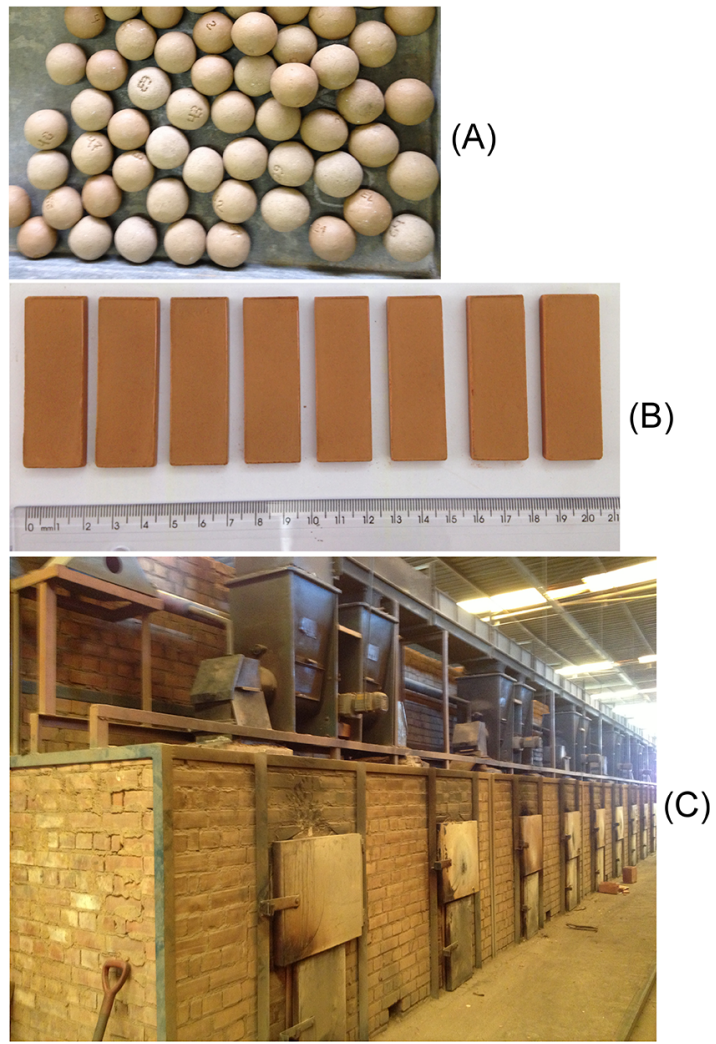

Figure 1. Details of specimens and the industrial furnace-type tunnel

Table 1. Chemical composition by XRF

\begin{tabular}{ccccc}
\hline \multicolumn{5}{c}{ Composition expressed in oxides (\% wt) } \\
\hline $\mathrm{SiO}_{2}$ & 41.83 & 43.62 & 40.85 & 43.39 \\
$\mathrm{Al}_{2} \mathrm{O}_{3}$ & 32.32 & 28.15 & 33.56 & 30.16 \\
$\mathrm{Fe}_{2} \mathrm{O}_{3}$ & 8.76 & 12.04 & 7.41 & 9.29 \\
$\mathrm{TiO}_{2}$ & 1.35 & 1.34 & 1.51 & 1.39 \\
$\mathrm{~K}_{2} \mathrm{O}$ & 0.92 & 1.02 & 0.77 & 1.25 \\
$\mathrm{MgO}$ & 0.71 & 0.38 & 0.63 & 0.62 \\
$\mathrm{CaO}$ & 0.24 & 0.16 & 0.21 & 0.24 \\
$\mathrm{Na}_{2} \mathrm{O}$ & 0.18 & 0.23 & 0.16 & 0.17 \\
$\mathrm{P}_{2} \mathrm{O}_{5}$ & 0.07 & 0.23 & 0.14 & 0.12 \\
$\mathrm{MnO}$ & $<0.05$ & $<0.05$ & $<0.05$ & 0.06 \\
$\mathrm{LOI}$ & 13.58 & 12.62 & 14.29 & 13.17 \\
\hline
\end{tabular}

Note: LOI: loss on ignition.

alumina, characteristic of the raw material of red ceramics with refractory character.

The values stipulated by Souza Santos ${ }^{2}$ of $\mathrm{SiO}_{2}$ between $43.2 \%$ and $77.6 \%$ and of $\mathrm{Al}_{2} \mathrm{O}_{3}$ between $6.8 \%$ and $38.0 \%$ were met in clays "B" and "D". The "A" and "C" clays, with $\mathrm{SiO}_{2}$ contents of $41.8 \%$ and $40.9 \%$ respectively, were very close to the minimum limit and met the limits of $\mathrm{Al}_{2} \mathrm{O}_{3}$ content. 


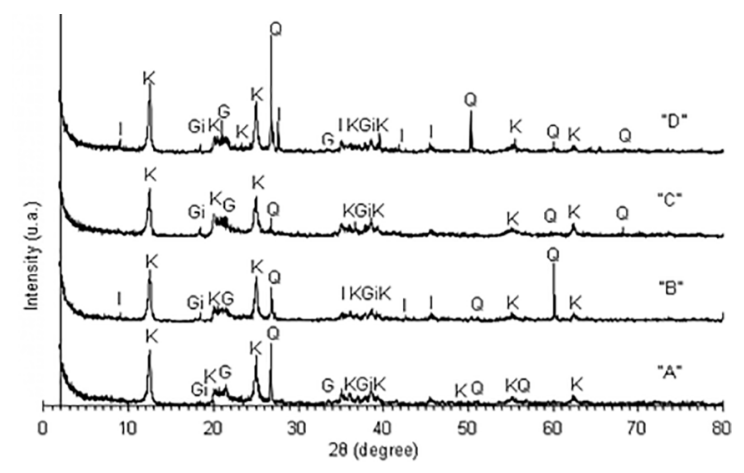

Figure 2. X-ray diffractogram of clays A, B, C, D

The high content of $\mathrm{Fe}_{2} \mathrm{O}_{3}$ is responsible for the reddish color after burning, which is a characteristic of the red ceramic products. The loss on ignition presented by the clays was close to the maximum limit of the range of $6.0 \%$ to $15.7 \%$ specific for kaolinite clay ${ }^{2}$. This relatively high loss on ignition is associated with the dehydroxylation of the clay minerals (kaolinite) and the oxidation of organic matter ${ }^{13}$ and it can cause high porosity in the ceramic pieces after burning ${ }^{14,15}$.

Alkaline oxides $\left(\mathrm{K}_{2} \mathrm{O}\right.$ and $\left.\mathrm{Na}_{2} \mathrm{O}\right)$ contribute little to the formation of the glassy phase due to the low content of all the clays. The presence of kaolinite in the clays can be related with the low contents of the alkali oxides and the high $\mathrm{SiO}_{2}$ and $\mathrm{Al}_{2} \mathrm{O}_{3}$ contents ${ }^{16}$.

The X-ray diffractogram (Fig. 2) indicates presence of kaolinite that confirms the result obtained in the XRF, since in general, clay with high content aluminum presents kaolinite as the main clay mineral ${ }^{17}$. Quartz, which is a crystalline form of silica found in the chemical analysis, was also detected. There are indications of the presence of goethite and gibbsite. There is probably presence of illite in clays $B$ and $D$.

Fig. 3 shows the images obtained in differential scanning calorimetry (DSC) and thermogravimetry (TG) of the clays. The thermal behavior of the four clays is very similar. The first endothermic peak occurred near $100^{\circ} \mathrm{C}$ (DSC curve), where there is the loss of free water between the particles. At around $260^{\circ} \mathrm{C}$ the endothermic peak occurred due to the combustion of organic matter and loss of water of the hydroxides, probably of the gibbsite and the goethite. The presence of the hydroxides results in the need for additional energy for their decomposition.

The highest intensity endothermic peak occurred at about $500^{\circ} \mathrm{C}$, characteristic of loss of hydroxyl in the clay minerals of the kaolinite group. After $500^{\circ} \mathrm{C}$, with the exit

\section{(A)}

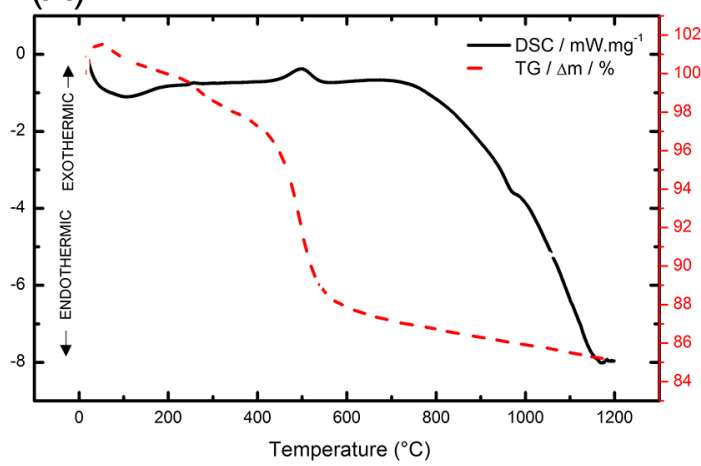

(C)

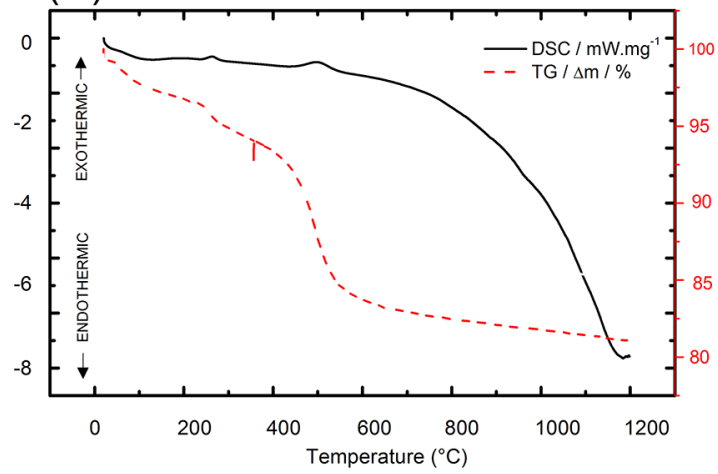

(B)

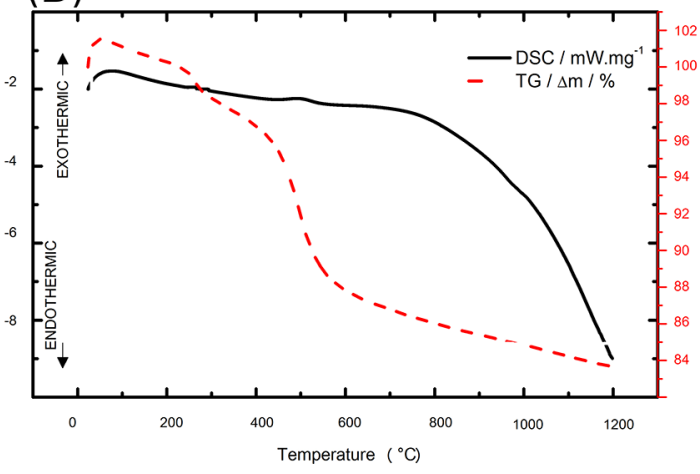

(D)

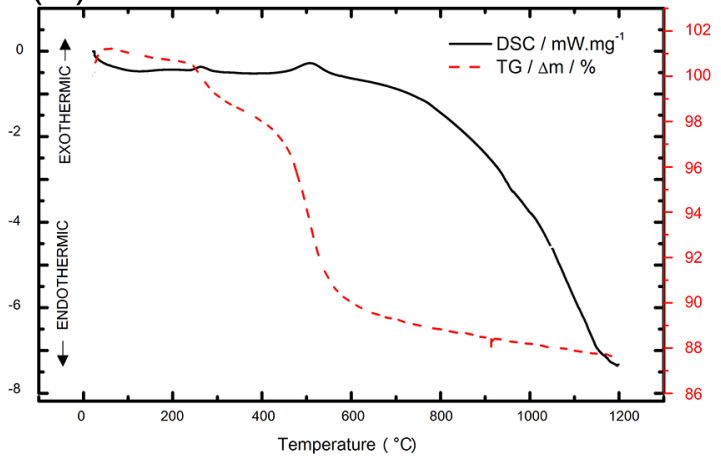

Figure 3. Curves DSC/TG of clays A, B, C, D 
of water, the crystallinity disappears and metacaulinite ${ }^{2}$, which is amorphous and metastable, begins to form. The vitrification phase that would begin near $900^{\circ} \mathrm{C}$ with the formation of spinel and the nucleation of mullite from $970^{\circ} \mathrm{C}$ has not been detected on the graph.

In the TG graph (Fig. 3), which shows the loss of mass with increasing temperature, it can be verified that the greatest mass loss in the clays occurred due to dehydroxylation of kaolinite at about $500^{\circ} \mathrm{C}$, and the total loss value was around: 15\% (Clay A), 16\% (clay B), 18\% (clay C) and 12\% (clay D), which are consistent values for kaolinite clays ${ }^{2}$ and corroborate the values found in FRX.

Fig. 4 shows the particle size distribution curves of the clays. The effective diameter $\left(\mathrm{d}_{10}\right)$ is obtained with the curve, value of the point of $10 \%$ of accumulated volume, such that $10 \%$ of the clay particles have a diameter smaller than it.

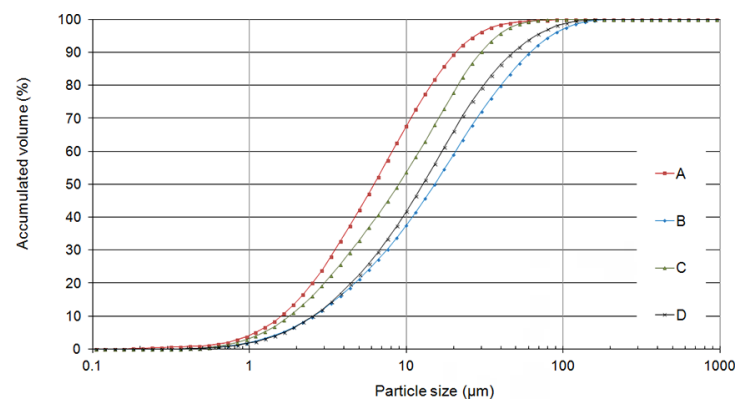

Figure 4. Particle size distribution curves of clays A, B, C, D

Table 2. Atterberg limits

\begin{tabular}{cccc}
\hline Clay & $\begin{array}{c}\text { Liquid limit } \\
\text { LL }(\%)\end{array}$ & $\begin{array}{c}\text { Plasticity } \\
\text { limit PL }(\%)\end{array}$ & $\begin{array}{c}\text { Plasticity } \\
\text { index PI (\%) }\end{array}$ \\
\hline A & 76.16 & 37.34 & 38.82 \\
B & 58.62 & 37.50 & 21.12 \\
C & 67.46 & 42.00 & 25.46 \\
D & 59.61 & 38.37 & 21.24 \\
\hline
\end{tabular}

Table 3. Organic matter content (O.M.)

\begin{tabular}{ccccc}
\hline Clay & A & B & C & D \\
\hline O. M.(\%) & 57 & 49 & 68 & 60 \\
\hline
\end{tabular}

Table 4. Average values of the ceramic properties on the bars

\begin{tabular}{|c|c|c|c|c|c|c|c|}
\hline Clay & LOI (\%) & WA (\%) & $\operatorname{AP}(\%)$ & $\operatorname{ASM}\left(\mathrm{g} / \mathrm{cm}^{3}\right)$ & $\mathrm{L}_{\mathrm{s}}(\%)$ & $\mathrm{L}_{\mathrm{Q}}(\%)$ & $\mathrm{FS}(\mathrm{MPa})$ \\
\hline A & 13.20 & 25.67 & 41.62 & 1.62 & 0.02 & 3.67 & 7.27 \\
\hline B & 12.62 & 24.77 & 41.34 & 1.62 & 0.07 & 2.36 & 4.23 \\
\hline $\mathrm{C}$ & 14.33 & 24.32 & 39.80 & 1.65 & 0.13 & 3.93 & 8.85 \\
\hline $\mathrm{D}$ & 12.16 & 24.17 & 39.33 & 1.63 & 0.11 & 1.74 & 3.71 \\
\hline 4clay & 12.49 & 25.10 & 40.78 & 1.63 & 0.09 & 1.63 & 4.35 \\
\hline Ref.(2) & - & $\leq 25.00$ & $\leq 35.00$ & 1.50 a 2.00 & 3 a $10^{*}$ & 2 a $17^{*}$ & $>6.00$ \\
\hline
\end{tabular}

Note: LOI: loss on ignition; WA: water absorption; AP: apparent porosity; ASM: apparent specific mass; LS: linear shrinkage of drying; LQ: linear shrinkage of burning; FS: flexural strength; 4clay: mixture of 4 clays; $\operatorname{Ref}^{(2)}$ : Souza Santos (1975);

* values for caulinitic clay.
The effective diameters $\left(\mathrm{d}_{10}\right)$ are: clay A of $1.825 \mu \mathrm{m}$, clay B of $2.935 \mu \mathrm{m}$, clay C of $2.061 \mu \mathrm{m}$, clay D of $2.917 \mu \mathrm{m}$. By means of the data obtained in the 4 clays it is observed that from $7 \%$ to $14 \%$ of the grains are smaller than $2 \mu \mathrm{m}$; $48 \%$ to $72 \%$ of the grains have sizes between $2 \mu \mathrm{m}$ and 20 $\mu \mathrm{m}$ and $14 \%$ to $45 \%$ of the grains are larger than $20 \mu \mathrm{m}$. This indicates that the clays have low "clay fraction" (grains smaller than $2 \mu \mathrm{m}$ ).

The Atterberg limits are shown in Table 2. The plasticity index (PI) indicates that the clays are highly plastic (PI $\geq$ $15)$, which may be related to the presence of organic matter, which influences the values obtained in the loss on ignition, from $12.6 \%$ to $14.3 \%$. This PI value causes the clays to demand a greater amount of water in the conformation, which should require a longer drying time. However, it results in satisfactory dry mechanical strength due to the good cohesion between the clay minerals present in the highly plastic clay ${ }^{18}$.

Regarding the plasticity limit (PL), in the case of kaolinite clays, the values found are within the range of $8.9 \%$ to $56.3 \%{ }^{2}$.

Table 3 presents the analysis of the organic matter content of the clays. It can be observed that the "C" clay presented higher content of organic matter, which may be related to the higher plasticity limit, since the increase of the organic matter tends to increase the specific surface area of the soil with consequent increase of water retention, leading to higher values for soil plasticity limits ${ }^{19}$.

The results obtained from the ceramic properties of the bars are presented in Table 4. Comparison was made with the limit values prescribed by Souza Santos $(1975)^{2}$.

Clays $\mathrm{A}$ and $\mathrm{C}$ met the minimum value of $6.0 \mathrm{MPa}$ for flexural strength (FS), with clay $\mathrm{C}$ having the highest apparent specific mass value (MEA), that is, it has greater compactness and strength mechanical properties compared to other clays. Clays B, C, and D met the maximum value of $25 \%$ for water absorption (WA), while clay A and mixture (4clay) did not meet. But, the apparent porosity (AP), with a maximum limit of $35 \%$, was not met by any clay or by mixing them, a fact that had already been observed due to the high loss on ignition the clays.

The values of loss on ignition (LOI) of the clays did not vary greatly and correspond to the values found in the XRF. 
Table 5. Average values of the ceramic properties on the spheres

\begin{tabular}{cccccccc}
\hline Clay & LOI $(\%)$ & WA $(\%)$ & AP $(\%)$ & ASM $\left(\mathrm{g} / \mathrm{cm}^{3}\right)$ & VS $_{\mathrm{D}}(\%)$ & $\mathrm{VS}_{\mathrm{B}}(\%)$ & $\sigma(\mathrm{MPa})$ \\
\hline A & 13.32 & 26.95 & 39.87 & 1.49 & 0.50 & 8.98 & $\mathbf{2 . 0 6}$ \\
B & 12.84 & 26.94 & 39.40 & 1.49 & 1.91 & 4.22 & 1.89 \\
C & 14.34 & 25.38 & 37.92 & $\mathbf{1 . 5 4}$ & 0.70 & 12.03 & $\mathbf{2 . 1 6}$ \\
D & 11.86 & 25.21 & 37.41 & 1.52 & 0.62 & 3.80 & 1.31 \\
4clay & 12.23 & 24.78 & 37.69 & 1.51 & 1.04 & 6.20 & $\mathbf{2 . 9 9}$ \\
\hline
\end{tabular}

Note: LOI: loss on ignition; WA: water absorption; AP: apparent porosity; ASM: apparent specific mass; $\mathrm{VS}_{\mathrm{D}}$ : volumetric shrinkage of drying; $\mathrm{VS}_{\mathrm{B}}$ : volumetric shrinkage of burning; $\sigma$ : compressive strength; 4clay: mixture of 4 clays.

Such value can contribute to the increase in the porosity of the pieces. The low values of linear shrinkage drying $\left(\mathrm{L}_{\mathrm{S}}\right)$ and after burning $\left(\mathrm{L}_{\mathrm{Q}}\right)$ were not a source of defects in the pieces.

Table 5 presents the results of the ceramic properties on the spheres. It is possible to verify the coherence between the spheres values and the bars values found, a fact also observed by Reis, Della-Sagrillo and Valenzuela-Diaz $(2016)^{20}$.

Clays $\mathrm{A}$ and $\mathrm{C}$ and the mixture of 4 clays (4clay) obtained the highest values of compressive strength, with clay $\mathrm{C}$ having the highest apparent specific mass value (ASM), that is, presenting greater compactness. The mixture of the four clays met the maximum value of $25 \%$ for the water absorption (WA) stipulated for the bars. However, the apparent porosity (AP), with a maximum limit of $35 \%$, was not met by any clay or by mixing them, a fact that had already occurred in the bars.

The values of loss on ignition (LOI), volumetric shrinkage after drying $\left(\mathrm{VS}_{\mathrm{D}}\right)$ and after burning $\left(\mathrm{VS}_{\mathrm{B}}\right)$ of the clays did not suffer much variation corroborating the results found in the bars.

\section{Conclusions}

The chemical and mineralogical characterization of clays A, B, C and D showed that the predominant mineral is kaolinite, and the clays are considered as "silica aluminous". The clays contain adequate quartz and iron contents. The samples have a particle size distribution with low "clay fraction" content, but they present high plasticity influenced by the organic matter content.

In the bars, clays $\mathrm{A}$ and $\mathrm{C}$ met the minimum value of flexural strength. The clay $\mathrm{C}$ presented the highest value of ASM (apparent specific mass), that is, it presented greater compactness and mechanical strength, both in the bars and in the spheres.

Bars with clays B, C, and D met the maximum value of $25 \%$ for water absorption. But the porosity was not met by any clay or by mixing them in both bars and spheres.

The results found in the bars and spheres are coherent. Thus, the methodology of spheres molding can be an alternative for the molding of specimens, because it is a simple and accessible technique for the characterization studies of the clays in the pottery itself.
The mixture formed by the four clays does not meet the values of the Brazilian standard-clays for use in red ceramics found in the literature regarding the apparent porosity, water absorption and mechanical strength. Possible interventions in the production process, such as, the increase in the burning temperature of the products in the factory can be suggested to meet the specified limits. Besides, a study in the industrial mixture to increase the content of the clay $\mathrm{C}$ in the dosage, which obtained better results in the ceramic properties evaluated in the bars and in the spheres, can also be suggested.

The technological characterization of the clays realized in this research allows verifying if they are suitable for the production of red ceramics, as well as the need for adjustments in the production process to improve the quality of the final products.

\section{Acknowledgment}

The authors thank CAPES-BR, IFES-BR and PMTEPUSP-BR.

\section{References}

1. Callister WD. Ciência e Engenharia de Materiais: Uma Introdução. $5^{\mathrm{a}}$ ed. Rio de Janeiro: LTC; 2002.

2. Souza Santos P. Tecnologia de Argilas. Vol. 1-2. São Paulo: Edgard Blucher; 1975.

3. Petrucci EGR. Materiais de Construção. $4^{\mathrm{a}}$ ed. Porto Alegre: Editora Globo; 1979.

4. Santos RC, Santana LNL, Macedo RS, Silva BJ. Formulação de massas cerâmicas para a produção de telhas. In: Anais do Congresso Brasileiro de Engenharia e Ciência dos Materiais; 2012 Nov 4-8; Joinville, SC, Brazil. Available from: <http:// www.metallum.com.br/20cbecimat/resumos/trabalhos completos/115-027.doc >. Access in: 19/10/2017.

5. Reis AS, Junca E, Grillo FF, Della-Sagrillo VP, ValenzuelaDiaz FR. Caracterização de argila para utilização em cerâmica vermelha estrutural. In: Anais do $69^{\circ}$ Congresso Anual da ABM; 2014 Jul 21-25; São Paulo, SP, Brazil. ABM; 2014.

6. Associação Nacional da Indústria Cerâmica (ANICER). Dados oficiais (on line). Rio de Janeiro. 2014. Available from: $<$ http:// www.anicer.com.br/index.asp?pg=institucional.asp \&secao $=3 \&$ categoria $=60 \&$ selMenu $=4>$. Access in: 28/02/2014. 
7. Morais DM, Sposto RM. Propriedades tecnológicas e mineralógicas das argilas e suas influências na qualidade de blocos cerâmicos de vedação que abastecem o mercado do Distrito Federal. Cerâmica Industrial. 2006;11(5-6):35-38.

8. Macedo RS, Menezes RR, Neves GA, Ferreira HC. Estudo de argilas usadas em cerâmica vermelha. Cerâmica. 2008;54(532):411417.

9. Associação Brasileira de Normas Técnicas (ABNT). NBR 6459: Solo - determinação do limite de liquidez. Rio de Janeiro: ABNT; 1984.

10. Associação Brasileira de Normas Técnicas (ABNT). NBR 7180: Solo - determinação do limite de plasticidade. Rio de Janeiro: ABNT; 1984.

11. Goldin A. Reassessing the use of loss-on-ignition for estimating organic matter content in noncalcareous soils. Communications in Soil Science and Plant Analysis. 1987;18(10):1111-1116.

12. COD - Crystallography Open Database. Open-access collection of crystal structures of organic, inorganic, metal-organic compounds and minerals, excluding biopolymers. 2015. Available from: $<\mathrm{http} / / / w w w . c r y s t a l l o g r a p h y . n e t />$. Access in: 23/2/2015.

13. Dias CACM. Reciclagem de lama de alto forno em cerâmica vermelha. [Thesis]. Campos dos Goytacazes: Universidade Estadual Norte Fluminense; 2011. 142 p.
14. Vieira CMF, Peçanha LA, Monteiro SN. Efeito da incorporação de resíduo de serragem de granito em massa de cerâmica vermelha. Vértices. 2003;5(3):143-157.

15. Vieira CMF, Pinheiro RM. Evaluation of kaolinitic clays from Campos dos Goytacazes used for red ceramic fabrication. Cerâmica. 2011;57(343):319-323.

16. Prado CMO. Caracterização química e mineralógica das argilas utilizadas na produção de cerâmica vermelha no estado de Sergipe. [Dissertation]. São Cristóvão: Universidade Federal de Sergipe; 2011.62 p.

17. Sales Jr JCC. Avaliação da potencialidade de argilas de queima clara como matérias-primas para o desenvolvimento de novos produtos cerâmicos. [Dissertation]. Natal: Universidade Federal do Rio Grande do Norte; 2008. 94 p.

18. Vieira CMF, Dias CACM, Mothé AV, Sánchez R, Monteiro $\mathrm{SN}$. Incorporation of blast furnace sludge into red ceramic. Cerâmica. 2007;53(328):381-387.

19. Silva AJN, Cabeda MSV, Carvalho FG. Matéria orgânica e propriedades físicas de um Argissolo Amarelo Coeso sob sistemas de manejo com cana-de-açúcar. Revista Brasileira de Engenharia Agrícola e Ambiental. 2006;10(3):579-585.

20. Reis AS, Della-Sagrillo VP, Valenzuela-Diaz FR. Analysis of the spheres and bars molded with blast furnace sludge incorporation in clayey mass. Research \& Reviews: Journal of Material Sciences. 2016;4(3):25-33. 